\title{
RESEARCH OF PARAMETERS OF INDUSTRIAL WATERS OF CANNING PLANT AND BAKERY.
}

\author{
Marianna Havryshko (Author 1) ${ }^{1}$, Olena Popovych (Author 2) ${ }^{2}$
}

1. Department of Ecology and Sustainable Nature Management, V. Chornovil Institute of Sustainable Development, Lviv Polytechnic National University, Ukraine, Lviv, S. Bandery street, 12, 79013, E-mail: marianna.i.havryshko@1pnu.ua

2. Department of Ecology and Sustainable Nature Management, V. Chornovil Institute of Sustainable Development, Lviv Polytechnic National University, Ukraine, Lviv, S. Bandery street, 12, 79013, E-mail: lpolenaeko@yahoo.com

\begin{abstract}
In recent decades, water pollution around the planet has become catastrophic. A significant role in the pollution of the hydrosphere is played by the processing industry. As a result, the surface water sources become more contaminated, the use of water for industrial, thermal, domestic and other needs determines the necessity in complex and costly treatment. So, the improvement and creation of conceptually new methods of food wastewater treatment is a relevant scientific and technological task today.
\end{abstract}

Key words: bakery, waste, sewage, ecological safety, food industry, cannery.

Wastewater from food industry enterprises is formed during the technological process, washing of raw materials, equipment, production facilities as well as after the use of water and steam in technological processes. The formed wastewater contains aggregatively stable colloids which include animal and vegetable fats, proteins, starch, sugar as well as salts, carbohydrates, dyes, thickeners, preservatives [1]

Contamination of surface waters with organic substances from food production effluents poses a significant environmental risk. These substances, which are brought in water, cause the development of decay processes in it, disturb the natural balance of water, cause eutrophication and negatively affect fauna and flora.

Wastewater treatment can be performed according to various schemes that provide high treatment efficiency. All methods of wastewater treatment currently used are divided into: mechanical, physicochemical, chemical, biological (biochemical). In addition, wastewater disinfection is used to destroy bacterial contamination.

In circulating and wastewater, contaminants in vegetable processing plants are soil particles, fruit pulp and peel, mold and rot bacteria, and other wastes. During the treatment of the same raw material, wastewater can differ significantly. For example, the composition of wastewater from vegetable processing enterprises includes: soluble, insoluble and colloidal substances that are removed from the surface of products during their cleaning and washing; juices and syrups used in the processing of products, impurities, waste from raw materials, etc are accidentally introduced. The size of these contaminants is significant, $12-35 \%$ from weight of raw materials. From 20 to $50 \%$ of waste enters the sewer network together with wastewater.

The technological scheme of industrial wastewater treatment of different composition includes the following units: averaging and accumulation of wastewater; mechanical cleaning from large residues; reagent (chemical, physicochemical, electrochemical, biotechnological) treatment of wastewater with the destruction of toxic and release in the form of a suspension of harmful (aggressive) impurities; aggregate formation (coagulation, flocculation) to intensify the process of removing the suspension from the drain; clarification (settling) of treated wastewater in high-speed (thin-layer) settling tanks; additional treatment (if necessary) of clarified water on granular filters; 
water disinfection as well as dehydration of the released suspension of pollutants and disposal of the formed sediments [2].

The analysis of wastewater parameters was carried out on the basis of existing food industry enterprises, namely a cannery and a bakery.

Water sampling from the cannery was carried out for 2 months and the control one after a year. Sampling of wastewater from the bakery was analyzed for 6 months. According to standard methods, the main indicators of water were determined and the compliance with the MPC was analyzed.

Thus, in accordance with the final results of wastewater analysis, the maximum allowable norms of ammonium nitrogen, BOD5 and COD were exceeded. Their concentrations at both plants were $9.8 \mathrm{mg} / \mathrm{dm}^{3}, 98 \mathrm{mg} / \mathrm{dm}^{3}$ and $254 \mathrm{mg} / \mathrm{dm}^{3}$ at the cannery and $3.24 \mathrm{mg} / \mathrm{dm}^{3}, 36 \mathrm{mg} / \mathrm{dm}^{3}$ and $78 \mathrm{mg} / \mathrm{dm}^{3}$ at the bakery, respectively, which exceeds the permissible norms several times (table 1).

At the same time, it should be noted that according to the latest results of the analysis of wastewater from the bakery, we can see an improvement in the degree of wastewater treatment, which indicates that the treatment system works and practically reaches its quality indicators, which unfortunately can not be said cannery, where the positive dynamics is not so clear.Also, in the wastewater of the cannery, as the result of changes in raw materials in the production process and the use of other detergents, the maximum permissible levels of phosphates and chlorides were recorded 10 and 2 times respectively, which confirms that all stages of the production process have an impact on high-quality wastewater composition.

Based on the obtained values and analyzing the ratio of BOD / COD, it is possible to offer the enterprises to improve the stages of biological treatment of industrial water to obtain quality indicators that meet the standards.

In particular, chemical oxygen demand (COD), oxidation by potassium permanganate indicates the presence of substances and their concentration when treated with strong oxidants. The value of the COD parameter is most evident in the determination of wastewater contamination before biochemical oxidation by estimating the ratio of $\mathrm{BOD} / \mathrm{COD}=0.7-0.8$, and for biochemically treated it is $0.4-0.1$.

\section{Conclusions.}

Wastewater from the food industry is highly concentrated in terms of organic impurities, suspended solids, may have unfavorable for biological treatment content of nutrients and $\mathrm{pH}$ values, but the analysis of the degree of biooxidation of organic impurities in relation to $\mathrm{BOD}_{5} / \mathrm{COD}$ showed that wastewater from the vast majority of food industry can be purified by biological methods.

After analyzing the dynamics of changes in pollutants in the wastewater of the bakery and cannery, we can conclude that the biological treatment systems at these enterprises do not function satisfactorily and clearly need improvement.

The considered biotechnology of wastewater treatment, which is successfully used in most food industries, can also be considered as a source of water for watering plants in the area to reduce overall water use in the process and return to the general process, for example to use for washing vegetables and fruit.

\section{Literature.}

[1] Symanyna P., Sydorskaia S. Stochnыe vodы pyshchevoi promыshlennosty. Sbornyk materyalov 72-y Studencheskoi nauchno-tekhnycheskoi konferentsyy, 20-28 aprelia 2016 h. / Belorusskyi natsyonalnыi tekhnycheskyi unyversytet, Fakultet hornoho dela y ynzhenernoi эkolohyy. Sektsyia «Эkolohyia». Mynsk, 2016. S. 178-183.

[2] Shestopalov O.V., Hetta O.S., Rykusova N.I.: Ekolohichni nauky.- 2019.- № 2(25).- S.20-27. 